\title{
The Signs of Digitalization on Food Safety Issues: A Literature Review Focusing on Traceability
}

\author{
ANNA FREUND* \\ *Corvinus University of Budapest, Department of Logistics and Supply Chain \\ Management; anna.freund@uni-corvinus.hu
}

DOI: $10.14267 / 978-963-503-867-1 \_04$

\begin{abstract}
This study aims to examine the signs of digitalization's/Industry 4.0's impact on food safety in form of a literature review. It is intended to awake the interest of both the academic sphere and internal (e.g., managers) and external (e.g., costumers, state) stakeholders of food producers and also processing companies. The main research questions focus on the methodology of tracing and tracking, which both have significant importance in the area of quality assurance especially in the food industry. From an economic point of view, we are now in the age of Industry 4.0, which has a major impact on the whole economy. Industry 4.0 solutions significantly are realized in the automation of data transfer. Excellent food safety conditions can be supported by real-time transmission, analysis, and interpretation of data characterizing products and processes. This study is an introductory part of the literature review of my doctoral research. The research goals include the exploration of Industry 4.0 and practices given by digitalization within different sectors of the food industry. Furthermore, establishing relationships between the measurability of food safety criteria and the toolbox of digitization and regulatory requirements are expected to be the results of the research process. The current study aims to introduce and interpret the basics of the connection between food safety and the toolbox of Industry 4.0. In general, the research may contribute both to the scientific area and the arena of practice.
\end{abstract}

Keywords: food safety, traceability, digitalization, Industry 4.0

Funding: The author did not receive any grant or institutional support in relation to the study's preparation. 


\section{Introduction}

Nowadays, due to digital technologies and Industry 4.0, which may connect them, the food industry can also be strongly involved in developments aimed at streamlining processes (Nagy, 2019; Nagy, Jámbor, \& Freund, 2020; Oláh, Popp, \& Erdei, 2019). In the current study, the author researches the digital solutions, as she assumes that digitization is the basis of Industry 4.0 (Nagy, 2019; Oláh et al., 2019). The study sees digitalization as a kind of entry-level, which may even be an indispensable starting point for future Industry 4.0 developments. In addition to other pioneering industries (manufacturing, automotive, SSC (shared service centers), logistics..., etc.), digitally coordinated methods and tools have emerged within the food industry, such as traceability, which is the focus of the current study (Demeter et al., 2020). In the following, the role of traceability within the food industry will be clarified, and in connection with it, the system of rules behind food safety will be presented. This part of the doctoral research aims to explore these possibilities and to find the connection between the applicable toolkit and the set of rules that include expectations. Based on the literature review the result of the research is, that the combined application of the three most prominent Industry 4.0 solutions found, CPS (Cyber Physical Systems), IoT (Internet of Things), and blockchain technology (Alladi, Chamola, Parizi, \& Choo, 2019; Bougdira, Akharraz, \& Ahaitouf, 2020; Creydt \& Fischer, 2019; Kayikci, Subramanian, Dora, \& Bhatia, 2020; Khan, Byun, \& Park, 2020; Lee, Azamfar, \& Singh, 2019; Lin, Wang, Pei, \& Wang, 2019; Oztemel \& Gursev, 2020; Prause, Hackfort, \& Lindgren, 2020; Smetana, Aganovic, \& Heinz, 2020; Y. Wang, Han, \& Beynon-Davies, 2019; Yadav, Luthra, \& Garg, 2020) can lead to the most effective implementation of traceability.

\section{Methods}

The author used the systematic literature review methodology set up by Brereton (Brereton, Kitchenham, Budgen, Turner, \& Khalil, 2007) to supplement her existing knowledge. The method describes a scientific validation mechanism. It seems to be applicable in almost any field, thanks to its comprehensive approach. The chapter shows by the author followed steps. 


\section{Research questions}

Three research questions are formulated. They focus on the exploration of the research field.

Q1: What case studies have been conducted in connection with food safety and traceability in the age of Industry 4.0 ?

Q2: Which areas of food safety have already used Industry 4.0 technologies?

Q3: What are the Industry 4.0 solutions that support food safety processes, such as traceability?

\section{Sources}

- Scopus (English speaking keywords)

- Web of Science (English speaking keywords)

- SpringerLink (English speaking keywords)

- Google Scholar (Hungarian speaking keywords)

It is always worth working with multiple search engines to get a comprehensive picture. The found results may be different (Brereton et al., 2007). Besides, where possible, sources should be sought in several languages. While preparing this short paper the author used Hungarian and English keywords.

\section{Keywords}

The author looks for the transferable best practices from the already mentioned industries (where I4.0 solutions are already applied), automotive, manufacturing, SSC, logistics..., etc. Because of this the research examines the various processes of the food industry and aims to find the supporting role of Industry 4.0. The study handles Industry 4.0 as it is "building on technological tools, raising the transparency of processes, integrating the corporate value chain and supply network to a new level, taking customer value creation to a new level, by exploiting the opportunities offered by digitalization and making customized and smart products available" (Nagy, 2019, p. 15). At this stage of the research, the focus within food safety is on traceability, so the following keywords were queried: "traceability" OR "standards" AND "food safety" AND "Industry 4.0". 


\section{Findings}

A total of 67 results in English and 8 in Hungarian were accessible. In addition to the keywords, the author also set the 2015-2020 custom range on each platform as a filter to supplement her existing literature knowledge (applied in previous explorations) with the latest contemporary literature.

\section{Selection of primary studies}

In addition to the expectations derived from the search terms, the author set up the following three criteria to screen the studies: case study or literature review; Hungarian or English speaking; and the scientific quality. The process of selection was the following. Because a manageable amount of resources was screened in both languages, the author read the studies with the above considerations in mind. She considered relevant sources that deal specifically with the monitoring of the food industry (the process did not include the field of agriculture in the analysis framework in the present situation).

\section{Synthesis of literature database}

The author used the methodology described above to supplement her existing funds, which she has already known in connection with traceability. The number of case studies seems to be less significant among the new findings. Experts introduce the topic mostly in the form of literature reviews. The following section describes the literature review.

\section{Theoretical background}

While introducing the theoretical background, three main areas will be in focus. The chapter begins with the basics of traceability. The second paragraph introduces the standards and regulations in connection with traceability. At the end of the literature review, the solutions provided by Industry 4.0 are described, which may contribute to the success of traceability. While introducing the theoretical background three main areas are highlighted.

\section{The role of traceability}

Digitalization might be mainly characterized by data collection, and this fact can be the starting point for product traceability. Traceability and the provision of continuous, realtime data can be the tool, which contributes to meet the needs of food safety standards and consumer trends. Traceability is a tool for monitoring the past, as well as to indicate 
possible intervention, it can be seen as a kind of input for data analysis, which serves as forecasts, and ultimately for prevention (GS1 web page, 2018). The importance of traceability is formulated by researchers, like ,food safety is a significant concern in the modern world; governments need to quickly formulate policies and take various measures to strengthen the management of the safe production of agricultural products, including identification and tracking" (Khan et al., 2020, p. 1).

Based on the collection of Olsen and Borit (Olsen \& Borit, 2013, p. 143) the ISO 8402: 1994, ISO 9000, ISO 22005, EU General Food Law, Codex Alimentarius Commission Procedural Manual (published by $\mathrm{FAO} / \mathrm{WHO}$ ) definitions are worth considering internationally.

Common to all approaches is that they see traceability as an ability to describe transparent, controllable movement between the start and endpoints. However, the difference in connection with ISO approaches is that it is much more general, even ISO 22005, which is a standard specifically for food safety conditions. Presumably, this is since ISO standards can be applied almost anywhere across industries, making the food industry specification less visible. The Codex Alimentarius Commission and the EU regulation focuses on the food supply chain perspective. According to Bougdira, Akharraz, and Ahaitouf (2020) traceability can be understood as a service as well. In the following paragraphs, it is shown, how traceability can be supported by organizations applying Industry 4.0 solutions.

\section{A system of standards that are for ensuring traceability}

Digitalization is based on the collection of data, which is the starting point for product traceability. Food business operators must pay attention to uniform food safety requirements. Behind the food industry, there is a complex system of requirements regarding quality expectations (Hungarian Food Book, HACCP guidelines, GMP (good manufacturing practice) regulation) (elelmiszerlanc.kormany.hu, 2021; Fda.gov.com, 2021; Njt.hu, 2021).

The laws currently in force in Hungary, as well as the relevant regulations, appear in the form of the following. The Hungarian Food Book formulates mandatory regulations, such as the most important HACCP principles and product bases, as well as the collection of testing methods (HACCP web page, 2020; Njt.hu, 2021). Compliance with the guidelines is mandatory for all food business operators. For example, the multi-volume extended

version of this is the GxP regulation developed by the US FDA which contains detailed requirements for all actors in the supply chain for the food and pharmaceutical industries 
(Fda.gov.com, 2021; Raspor, 2008; Wu et al., 2010, p. 45). The FAO / WHO Codex Alimentarius is the globally applied system of standards. Hygiene and technical guidelines have been formulated, and in the case of products intended for human consumption, maximum permitted levels of pesticide residues in food have been stated (FAO web page, 2021). The next one is the GS1 Traceability Standard, which is intended to complement the standards already used (GFSI (Global Food Safety Initiative), ISO), helping to facilitate their application. The GS1 Tracking Standard is considered to be an open standard, aiming to achieve continuity of tracking at the entire supply chain level. The GS1 Standards System creates an information flow linked to the flow of goods, based on three steps: identification, marking, data collection, and sharing (GS1 web page, 2018).

\section{Industry 4.0 toolkit to support compliance with standards}

The concepts of CPS, IoT, cloud, sensors, and blockchain have emerged in the literature concerning the concept of Industry 4.0 (Bibi et al., 2017; Carpenter \& Wyman, 2016; Demeter et al., 2020; Keller, Rosenberg, Brettel, \& Friederichsen, 2014; Tse et al., 2017; G. Wang, Gunasekaran, Ngai, \& Papadopoulos, 2016; Y. Wang et al., 2019). The author hypothesizes that the tools presented can be divided into two main parts, hardware, and software (Demeter et al., 2020; Keller et al., 2014). In addition to the tools that make it suitable for tracking, there is also a need for a sphere through which the processes can function (Nagy et al., 2020). Industrial digitalization is in the middle of the concept. Implementation of this requires hardware that can collect data. On the other hand, the software makes the system suitable for handling data.

Based on these, food products equipped with a network-capable device (chip, RFID, sensor) are suitable for real-time data transmission (Mishra et al., 2016). Big data is generated from the accumulated data, after which the big data analysis can provide decision support assistance, as well as the opportunity for examination, tracking, and possibly intervention (GS1 web page, 2018; G. Wang et al., 2016). The storage of large amounts of data can be provided by cloud-based repositories, while in the case of IoT (Internet of Things) the focus is on the communication of "things". Based on the current systematic literature review, the following Industry 4.0 solutions contribute the most to traceability. 
Table 1. Collected sources

\begin{tabular}{ll}
\hline Area & Authors \\
\hline blockchain & Alladi et al. 2019; Creydt and Fischer 2019; Kayikci et al. 2020; \\
& Khan et al. 2020; Prause et al. 2020 \\
IoT (Internet of Things) & Bougdira et al. 2020; Khan et al. 2020; Prause et al. 2020; \\
& Yadav et al. 2020 \\
CPS (Cyber-Physical Systems) & Bougdira et al. 2020; Lee, Azamfar, and Singh 2019; Oztemel \\
& and Gursev 2020; Smetana et al. 2020 \\
\hline
\end{tabular}

Source: own edition

\section{Blockchain}

Reading the literature, the most frequently mentioned I4.0 solution seems to be the blockchain, which supports food safety processes (Alladi et al., 2019; Creydt \& Fischer, 2019; Kayikci et al., 2020; Khan et al., 2020; Lin et al., 2019). Examining the definitions of blockchain given by the recent theoretical studies, it is conspicuous that the common phrases raising are: traceability, efficiency, and information storage.

„Within the blockchain, a (public) ledger is used for recording the data, as well as the information of each transaction. Information about each completed transaction is stored in a distributed ledger, shared across all the participating nodes of the blockchain network" (Alladi et al., 2019, p. 176935).

According to experts (Beck, Czepluch, Lollike, \& Malone, 2016) the mechanism of blockchain can be described like there are different blocks within the chain connected. Each block contains data about all transactions made within a given period. The technology of blockchain allows that the content of the blocks is not able to be changed retrospectively. It functions as a „digital footprint" and contributes to the validation process of the information. Some experts also state that blockchain can serve ,the transparency from farm to fork" (Creydt \& Fischer, 2019, p. 49).

Blockchain might serve as a sphere, like a virtual space, whereby the hardware tools collected data can be shown and even shared or controlled in real-time (Wang et al., 2019). The research group of Kayicky (Kayikci et al., 2020) adds another perspective to the question regarding food loss and food fraud. Blockchain technology empowers traceability processes to work while avoiding them. Based on this, blockchain as a traceability supporter contributes to raising trust in connection with business transactions providing transparency. 


\section{IoT (Internet of Things)}

Three technologies characterize mostly the operation of the Internet of Things. Sensors (1) record the data of processes and pieces of equipment. To share the data network (2) connection is needed. Cloud (3) technology provides access to the corporate data center. Data can be stored and shared by using clouds (Prause et al., 2020; Yadav et al., 2020). According to the research group of Bougdira, „IoT refers to a set of devices and technologies that could share resources and intelligence" (Bougdira et al., 2020, p. 3355) Experts, like Khan (Khan et al., 2020) explain IoT as a solution, which provides aggregated information produced by the participants of the food supply chain. Based on this IoT is a combined solution, which enables the devices to cooperate and serve the data collection and storage of companies.

\section{CPS (Cyber Physical Systems)}

CPS is comprehensible as a tool, which contributes to the cooperation of human and nonhuman entities within a process. It provides easy communication capability between people, machines, or even products during whole business processes while existing as a link between them (Keller et al., 2014; Oztemel \& Gursev, 2020). According to the research group of Bougdira (Bougdira et al., 2020) CPS is a need to let traceability function within a system. CPS-based solutions are often complex ones. Furthermore, they have an integrative role between the machine word and the cyber computational space (Lee et al., 2019). To CPS belong the usage of RFID tags (ensuring identification), sensors (serving data collection), and also the network, which is the sphere where the collected data can be transported (Oztemel \& Gursev, 2020; Smetana et al., 2020). According to experts (Khan et al., 2020), there are three main areas where the combination of IoT and blockchain technologies can be applied: provenance, payments, and management. Based on this and the previously introduced literature background, it is visible that not only individual parts of solutions exist in connection with traceability. They might cooperate and be combined, such as IoT and blockchain technologies (Kayikci et al., 2020; Khan et al., 2020; Lee et al., 2019; Oztemel \& Gursev, 2020; Prause et al., 2020; Smetana et al., 2020). The author aimed to describe these I4.0 technologies and highlight the importance of customized solutions concerning food safety. 


\section{Conclusion and recommendations}

This literature review aims to highlight the importance of food traceability and show some modern technological solutions, which can contribute to efficient operation. The research questions (Q1, Q2, and Q3) focused on traceability and Industry 4.0 connections. It is visible that Q1 couldn't be answered. Since mainly literature reviews were found (instead of case studies) this lets the author conclude that the researched technologies haven't been frequently applied within the food industry. The literature reviews on the other hand show that various Industry 4.0 solutions are available, so it is worth continuing the research this way. Q2 wanted to examine the areas of food safety, which the researched Industry 4.0 solutions can support. It is was found that mainly traceability, food loss, or even food fraud (Kayikci et al., 2020) are the areas where monitoring, control, feedback, and cost-reduction factors seem to be important. While examining the answers given to Q3, three main Industry 4.0 solutions came up, as specific supporters of food traceability (Alladi et al., 2019; Bougdira et al., 2020; Kayikci et al., 2020; Khan et al., 2020; Lee et al., 2019; Oztemel \& Gursev, 2020; Prause et al., 2020; Smetana et al., 2020). Blockchain, IoT, and CPS solutions were mostly mentioned in the monitored literature. Blockchain was mentioned the most, it is the reason, why it is presented the most in detail. Based on the introduced theories the efficiency of traceability might be able to be increased by combining the I4.0 solutions. There are some difficulties, like that these solutions are rather costly investments and the implementation of the Industry 4.0 solutions would work efficiently, only in case if all of the participants of the food supply chain invested into implementing them. This requirement may cause difficulties.

There are some limitations of the used methodology. Not only case studies or literature reviews should be observed, but also a wider scale of theoretical background should be examined. It could contribute to gain more detailed sources. Widening the language choice (English, Hungarian, German, maybe Russian) would be also a useful decision, to get to know the best practices, existing theories within the examined region. As it is seen, the ratio of the standards and legal requirements is bigger than the introduced solution. Later a change of focus would be also an appropriate choice. Further directions are the research of other supportive solutions of food safety, and the author aims to develop some calculations/guidelines, which may help practitioners in decision making in connection with Industry 4.0 based developments. 


\section{References}

Alladi, T., Chamola, V., Parizi, R. M., \& Choo, K. K. R. (2019). Blockchain Applications for Industry 4.0 and Industrial IoT: A Review. IEEE Access, 7, 176935-176951. https://doi.org/10.1109/ACCESS.2019.2956748

Beck, R., Czepluch, J. S., Lollike, N., \& Malone, S. (2016). Association for Information Systems AIS Electronic Library (AISeL) BLOCKCHAIN - THE GATEWAY TO TRUSTFREE CRYPTOGRAPHIC TRANSACTIONS. Twenty-Fourth European Conference on Information Systems (ECIS), Istanbul, Turkey, 6(May), 4013-4027.

Bibi, F., Guillaume, C., Gontard, N., \& Sorli, B. (2017). A review: RFID technology having sensing aptitudes for food industry and their contribution to tracking and monitoring of food products. Trends in Food Science and Technology, 62, 91-103. https://doi.org/10.1016/j.tifs.2017.01.013

Bottani, E., \& Rizzi, A. (2008). Economical assessment of the impact of RFID technology and EPC system on the fast-moving consumer goods supply chain. International Journal of Production Economics, 112(2), 548-569. https://doi.org/10.1016/j.ijpe.2007.05.007

Bougdira, A., Akharraz, I., \& Ahaitouf, A. (2020). A traceability proposal for industry 4.0. Journal of Ambient Intelligence and Humanized Computing, 11(8), 3355-3369. https://doi.org/10.1007/s12652-019-01532-7

Brereton, P., Kitchenham, B. A., Budgen, D., Turner, M., \& Khalil, M. (2007). Lessons from applying the systematic literature review process within the software engineering domain. Journal of Systems and Software, 80(4), 571-583.

https://doi.org/10.1016/j.jss.2006.07.009

Carpenter, G., \& Wyman, O. (2016). Food manufacturing - Are you ready for Industry 4.0? https://www.marsh.com/uk/insights/research/food-manufacturing-are-you-ready-forindustry.html

Creydt, M., \& Fischer, M. (2019). Blockchain and more - Algorithm driven food traceability. Food Control, 105(March), 45-51. https://doi.org/10.1016/j.foodcont.2019.05.019

Demeter, K., Losonci, D., Marciniak, R., Nagy, J., Móricz, P., Matyusz, Z., ... Diófási-Kovács, O. (2020). Industry 4.0 through the lenses of technology, strategy, and organization A compilation of case study evidence. Vezetéstudomány / Budapest Management Review, 51(11), 14-25. https://doi.org/10.14267/veztud.2020.11.02

elelmiszerlanc.kormany.hu. (2021). https://elelmiszerlanc.kormany.hu/magyar-elelmiszerkonyv FAO web page. (2021). FAO web page. http://www.fao.org/fao-who-codexalimentarius/codextexts/list-standards/en/

Fda.gov.com. (2021). https://www.fda.gov/food/guidanceregulation/cgmp/ucm110907.htm

GS1 web page. (2018). Magyarországi útmutató az élelmiszereknyomonkövetésére vonatkozó elő́rások betartásához.

https://gs1hu.org/data/documents/NENYP_Osszesitett_Utmutato_v1_0_20180418.p $\mathrm{df}$

HACCP web page. (2020). HACCP web page. https://haccpmentor.com/cleaning/gmp-in-thefood-industry/ 
Kayikci, Y., Subramanian, N., Dora, M., \& Bhatia, M. S. (2020). Food supply chain in the era of Industry 4.0: blockchain technology implementation opportunities and impediments from the perspective of people, process, performance, and technology. Production Planning and Control, O(0), 1-21. https://doi.org/10.1080/09537287.2020.1810757

Keller, M., Rosenberg, M., Brettel, M., \& Friederichsen, N. (2014). Bluetooth Based Home Automation System Using Cell Phone Bluetooth Based Home Automation System. International Journal of Mechanical, Aerospace, Industrial, Mechatronic and Manufacturing Engineering, 8(1), 37-44.

Khan, P. W., Byun, Y. C., \& Park, N. (2020). IoT-blockchain enabled optimized provenance system for food industry 4.0 using advanced deep learning. Sensors (Switzerland), 20(10), 1-24. https://doi.org/10.3390/s20102990

Lee, J., Azamfar, M., \& Singh, J. (2019). A blockchain enabled Cyber-Physical System architecture for Industry 4.0 manufacturing systems. Manufacturing Letters, 20, 34-39. https://doi.org/10.1016/j.mfglet.2019.05.003

Lin, Q., Wang, H., Pei, X., \& Wang, J. (2019). Food Safety Traceability System Based on Blockchain and EPCIS. IEEE Access, 7, 20698-20707. https://doi.org/10.1109/ACCESS.2019.2897792

Mishra, D., Gunasekaran, A., Childe, S. J., Papadopoulos, T., Dubey, R., \& Wamba, S. (2016). Vision, applications and future challenges of Internet of Things: A bibliometric study of the recent literature. Industrial Management and Data Systems, 116(7), 1331-1355. https://doi.org/10.1108/IMDS-11-2015-0478

Nagy, J. (2019). Az ipar 4.0 fogalma és kritikus kérdései - vállalati interjúk alapján. Vezetéstudomány / Budapest Management Review, 50(1), 14-26. https://doi.org/10.14267/veztud.2019.01.02

Nagy, J., Jámbor, Z., \& Freund, A. (2020). Az ipar 4.0 és a digitalizáció legjobb gyakorlatai a hazai élelmiszergazdaságban. Vezetéstudomány / Budapest Management Review, 51(6), 5-16. https://doi.org/10.14267/veztud.2020.06.02

Njt.hu. (2021). 152/2009. (XI. 12.) FVM rendelet. Geraadpleegd van http://njt.hu/cgi_bin/njt_doc.cgi?docid=126175.366212

Oláh, J., Popp, J., \& Erdei, E. (2019). A jöv ő kihívásai. LOGISZTIKAI TRENDEK ÉS LEGJOBB GYAKORLATOK, 5(1), 12-19. https://doi.org/10.21405/logtrend.2019.5.1.12

Olsen, P., \& Borit, M. (2013). How to define traceability. Trends in Food Science and Technology, 29(2), 142-150. https://doi.org/10.1016/j.tifs.2012.10.003

Oztemel, E., \& Gursev, S. (2020). Literature review of Industry 4.0 and related technologies. Journal of Intelligent Manufacturing, 31(1), 127-182. https://doi.org/10.1007/s10845018-1433-8

Prause, L., Hackfort, S., \& Lindgren, M. (2020). Digitalization and the third food regime. Agriculture and Human Values, (September). https://doi.org/10.1007/s10460-020-101612

Raspor, P. (2008). Total food chain safety: how good practices can contribute? Trends in Food Science and Technology, 19(8), 405-412. https://doi.org/10.1016/j.tifs.2007.08.009 
Smetana, S., Aganovic, K., \& Heinz, V. (2020). Food Supply Chains as Cyber-Physical Systems: a Path for More Sustainable Personalized Nutrition. Food Engineering Reviews. https://doi.org/10.1007/s12393-020-09243-y

Tse, D., Zhang, B., Yang, Y., Cheng, C., \& Mu, H. (2017). Blockchain application in food supply information security. 2017 IEEE International Conference on Industrial Engineering and Engineering Management. https://doi.org/10.1109/IEEM.2017.8290114

Wang, G., Gunasekaran, A., Ngai, E. W. T., \& Papadopoulos, T. (2016). Big data analytics in logistics and supply chain management: Certain investigations for research and applications. International Journal of Production Economics, 176, 98-110. https://doi.org/10.1016/j.ijpe.2016.03.014

Wang, Y., Han, J. H., \& Beynon-Davies, P. (2019). Understanding blockchain technology for future supply chains: a systematic literature review and research agenda. Supply Chain Management, 24(1), 62-84. https://doi.org/10.1108/SCM-03-2018-0148

Wu, X., Wu, H., Xia, L., Ji, K., Liu, Z., Chen, J., ... Wu, Y. (2010). Socio-technical innovations for total food chain safety during the 2008 Beijing Olympics and Paralympics and beyond. Trends in Food Science and Technology, 21(1), 44-51. https://doi.org/10.1016/j.tifs.2009.10.010

Yadav, S., Luthra, S., \& Garg, D. (2020). Internet of things (IoT) based coordination system in Agri-food supply chain: development of an efficient framework using DEMATEL-ISM. Operations Management Research. https://doi.org/10.1007/s12063-020-00164-x 